\title{
STUDY ON BUDGET REVENUE COLLECTION, SHADOW ECONOMY AND TAX LOSSES CAUSED BY IT
}

\author{
Claudia Florina Radu PhD \\ "Vasile Goldis" Western University of Arad, Romania \\ e-mail: raduclaudiaf@gmail.com \\ Florin Cornel Dumiter PhD \\ "Vasile Goldis" Western University of Arad, Romania \\ e-mail: fdumiter@yahoo.com \\ Lavinia Dudas PhD \\ "Vasile Goldis" Western University of Arad, Romania \\ e-mail: laviniamustea@gmail.com \\ Stefania Master Jimon Student \\ "Vasile Goldis" Western University of Arad, Romania \\ e-mail: jimonstefania@yahoo.com
}

(Received November 2016; Accepted April 2017)

\begin{abstract}
Tax avoidance is a phenomenon faced by all countries, to a lesser or greater extent, and we can say that it has begun to manifest itself since the introduction of taxes. It is known that generally taxes are not pleasing to taxpayers, especially when their level is high. However, it is important for individuals, as a whole, not to evade from their tax obligations. In this context taxes can be regarded as a necessary evil to ensure the resources needed for state functioning. But often some taxpayers are looking for ways to avoid taxes, engaging either in tax evasion to the shelter of the law or in fraudulent evasion. In this paper we present some of the aspects that motivate individuals to pay taxes. Also we analyze the situation of budgetary revenues in Alba County and also the evolution of the main income of consolidated general budget in Romania. In the end of the paper we intend to draw a parallel between shadow economy, tax burden and tax losses due to shadow economy for a sample of 32 countries. In this way we can see where underground economy and tax losses have the highest values and where are required measures to mitigate them.

Keywords: tax evasion, shadow economy, tax burden, revenue, budget
\end{abstract}

JEL Classification: H26, H61, O17

\section{Introduction}

There are a number of studies indicating that higher probabilities of control have as effect a rise of income declared by taxpayers, and establishing higher fines can slow down tax evasion. But it has been found that in order to be effective, the fines should be combined with high rates of fiscal control. However it was also observed that oppressive tax laws and the harassment of taxpayers determine an increase of 
Radu C.F., Dumiter F.C., Dudas L., Jimon S. (2017)

Study on budget revenue collection, shadow economy and tax losses caused by it

resistance in paying taxes and abusive sanctions present a hostile impact on attitudes towards taxes and tax administration (Kirchler et al., 2007, pp. 10-15).

So in order to discourage tax evasion it is necessary to charge penalties high enough for evaders and also to increase the probability of being caught. By fines and penalties it is possible to diminish the shadow economy. But in the fight against tax evasion the following aspects must be taken into account: Firstly, it is necessary for the fines to be high enough to determine the taxpayers to declare their income correctly. On the other hand, draconian fines are not desirable, because in these conditions the tax system would be seen as inequitable, and of course we can talk about a resistance of individuals from paying taxes. They will seek to use any fiscal artifice for paying lower taxes. Therefore, a balance between these two aspects must be found.

We can say that self-employed individuals have more means to evade paying taxes, compared to employees, because for employees the withholding method is used. Also, those with higher incomes are more predisposed to evasion, because they have resources to appeal to tax advisors and then they will speculate the gaps from the tax laws. So not everybody has the ability to cheat at paying taxes because some of them lack the necessary methods or knowledge.

In the case of easily obtained revenues the taxpayers are more tempted to evade from paying taxes, while if revenues were earned through hard work, taxpayers generally have a higher aversion to risk and would not want to lose revenue by paying some fines.

Tax authorities should take measures in order to combat tax evasion, reduce it and also to increase tax compliance. Tax evasion is higher when tax compliance is low and vice-versa.

From the beginning we mention that issues relating to budgetary revenue collection refers to Alba county and then comparatively to Romania. Also aspects of the tax burden and shadow economy were presented for the 32 countries surveyed.

The study is divided into two parts: in the first part we have as purpose to highlight budget incomes collected in Alba County and also incomes of the consolidated general budget from our country. Then in the second part we analyze comparatively the tax burden, shadow economy and tax losses caused by it, on a sample of 32 Countries ( $28 \mathrm{EU}$ and four non-EU Countries). We try to see whether countries where the tax burden is high are also characterized by a large underground economy or not, since it is known that when the tax burden is very high, the temptation of individuals to evade taxes increases.

The paper is organized as follows: literature review, methodology, then results and discussions and finally some conclusions. 


\section{Literature review}

Osmani (2015, p. 18) highlighted that the legalization of the shadow economy within the legal economic activity will stabilize public finances, reduce fiscal costs for businesses and population, and would eliminate irregularities in the labour market and in the markets of goods and services. He also mentioned that countries of Southeast Europe (SEE) continue to be confronted with a huge shadow economy, tax evasion and corruption as a result of the prolonged economic transition. Due to large fiscal evasion these countries present high fiscal deficits in pension and public health funds and increasing public debt.

Murphy (2011, p. 2) underlined that tax evasion costs the world $\$ 3.1$ trillion a year, that means more than $5 \%$ of world GDP.

We may remark that evasion would be less tempting if every individual could quit, to some extent, to public goods and services of which can benefit, for each unit of evasion. When evasion is widespread less money is collected at the budget and thus the amount of public expenditures the individuals could benefit from becomes lower. Instead, if evasion is diminished there would be more money at the budget for public goods and services and individual satisfaction would increase. When, in a country too many persons avoid taxes, collective purposes can no longer be achieved. That is why, the tax can be seen as a necessary evil to ensure the resources needed for state functioning, and from this perspective it is useful for individuals to cooperate and each to pay their taxes (Radu, 2014 a, p. 108).

There are some opinions that the size of tax evasion would not depend only on the probability of detection and the punishment size. Thus morality or "tax consciousness" could explain to some extent the degree of tax compliance.

Bernasconi et al. (2011, pp. 6-7) are of the opinion that there are several dimensions (institutional, ethical, emotional) that influence the taxpayers perception on the fair taxes that should be paid. Thus, the moral attitude of taxpayers depends on: social norms, the quality of fiscal institutions, emotions, quality of public expenditure, the perceived fiscal equity. It is specified that a fiscal policy based on numerous controls and fines has effect when the trust in authority is low. But if the confidence degree is high, then the perceived justness of the tax system and tax morality are important. For maintaining a high tax compliance it is required for the taxpayers to consider authorities as being trustworthy and amiable (Kirchler et al., 2007, p. 18).

Many authors have sustained that tax morality can explain a high level of tax compliance. Thus some taxpayers are simply not inclined towards evasion and do not seek ways to avoid taxes, always being honest (Torgler et al., 2009, pp. 2-3). Non-monetary factors such as morality, norms, social consciousness and attitudes 
towards government can explain non-participation of individuals in tax evasion (Alstadsaeter, Jacob, 2013, p.1).

Bayer and Sutter (2004, p. 27) identify two main reasons why people do not avoid paying taxes: loss aversion and moral constraints, and moral constraints can effectively discourage tax avoidance.

There is another aspect, correlated to tax evasion: the way that taxpayers' money is spent. Perception of the tax system as being equitable, government expenditures as efficient and politicians as honest people showed that might diminish tax evasion (Bayer, Sutter, 2004, p. 27).

Some studies link the tax burden with tax avoidance, considering the high tax rates as responsible for high evasion. Therefore small reductions in the tax rates can produce a greater change in the behavior of taxpayers and actually can make them declare, to a greater extent, their earnings reputably (Papp, Takats, 2008, p. 3). Instead, a growth of the tax rate leads to more income hidden from tax authorities (Panades, 2004, p. 193).

Another aspect that can influence the budget revenues is represented by tax incentives granted to foreign investors (policy incentives). Dumiter and Todor (2014, p. 5) mentioned that these have the immediate effect of reducing budget revenues. But in the long - run, as investments mature, it may be an increase in revenue to the state budget through taxes paid by new payers (companies and workers).

Maciejovski et al. (2011, p. 13) argued that if it is hard to find reasons for paying taxes individuals will consider there is not a compelling justification for their payment and they will engage in higher levels of tax avoidance.

We believe that individuals pay taxes, firstly due to real or perceived benefits they think they can get by paying taxes. Secondly, for fear of negative consequences that could arise due to non-payment of them and only thirdly (and to a lesser extent) because of "fiscal consciousness" and due to a desire to help achieve "the common good". So usually people pay their taxes primarily to take advantage of adequate social benefits and then for not being exposed to the risk of paying fines. Fiscal morality actually relies heavily on law. It is true that moral constraints may discourage tax evasion, but that's also because of the existence of laws. Individuals are afraid that they will be caught and will be punished (Radu, 2014 a, p. 109).

On the other hand, it is important for issues of compliance or non-compliance of tax legislation to be linked to tax burden and reversibility of taxes in each country. If we take as example the Nordic countries, there is a high level of taxation, but also taxpayers benefit of substantial advantages from the state. So individuals will engage less in tax evasion and the level of compliance will be higher if they consider that public funds are used in their benefit and are not dissipated.

4 DE GRUYTER OPEN
Studia Universitatis "Vasile Goldis" Arad. Economics Series Vol 27 Issue 2/2017 ISSN: 1584-2339; (online) ISSN: 2285 - 3065

Web: publicatii.uvvg.ro/index.php/studiaeconomia.Pages 1 - 18 
In our opinion, among the factors influencing the payment of taxes by taxpayers, we can mention (Radu, 2014 b, p.117):

- The size of the positive consequences for taxpayers and their families arising from taxes payment, this amount being influenced by the perception about reversibility of taxes, i.e. the extent to which the state uses public money in the interest of taxpayers.

- The size of the perceived negative consequences resulting from the nonpayment of taxes and contributions.

- The size of the positive consequences for other members of society, meaning the measure in which the taxpayer wishes voluntarily to participate at the proper functioning of the community in which he manifests himself, for achieving the common good in a relatively disinterested way.

\section{Methodology and data}

The purpose of this paper is to draw a parallel between budgetary revenues collected and fiscal pressure, the shadow economy and tax losses due to it. So in the first part of the paper we chose to present the situation of budgetary income collected in Alba County over the period 2010-2015, highlighting also the main budget incomes, then we present comparatively the revenues collected to consolidated general budget in our country between years 2014-2015. Therefore, we consider useful the presentation of revenues from Alba County as part of the article.

Tax burden calculated as total mandatory levies as a percentage of GDP is the expression of budget revenues (together with social contributions) collected in a country. And this tax burden will be analyzed in the second part of the paper in correlation with the shadow economy and tax losses due to it/caused by it for 32 countries, including Romania. Thus we can draw some conclusions regarding countries where the tax burden has the highest value, respectively the lowest, then the countries where the underground economy and tax losses have the highest levels and the lowest. Therefore we can see where there is urgent need to implement measures aimed at alleviating shadow economy and tax evasion.

As methods, we used descriptive statistics method and comparison.

We took the data for Alba County from the website of the Ministry of Public Finance. Firstly we analyzed the evolution in dynamics of incomes at consolidated general budget of Alba County between 2010 and 2015. We have also presented the structure of revenues and the taxes with the largest share in total income. Then we presented comparatively the main incomes of consolidated general budget in Romania, the data being taken also from the website of the Ministry of Public Finance. 
We have found the data about tax burden and shadow economy as \% of GDP from the website www.oecd.org. Calculations on tax losses due to shadow economy were taken from the study Tax Losses due to Shadow Economy Activities in OECD Countries from 2011 to 2013: A preliminary calculation, of the author Schneider, F. (2016), Turkish Economic Review Vol. 3 (1), pp. 8-9. We mention that Friedrich Schneider in his study made certain corrections to the calculations made by Richard Murphy (2011) in the article The Cost of Tax Abuse: A briefing paper on the cost of tax evasion worldwide, for the Tax Justice Network, specifying that these have been overvalued.

We mention that the author Schneider F. published an article in 2015 which analyzes only the evolution of shadow economy during 2003-2015 for 36 OECD countries, but data for 2015 are projections only, as he himself specified. Also we are interested in our article of the data for tax losses due to shadow economy, but they are calculated by the author only in the Article from 2016 (and the most recent data are for 2013).

Therefore our analysis of the tax burden, shadow economy and tax losses for the 32 countries concerns the year 2013.

\section{Results and discussions}

\subsection{Budgetary incomes collected in Alba County and at the consolidated general budget in Romania}

Further we highlight the evolution of the main budgetary revenue from Alba County within the last six years.

Table 1 presents the main budgetary revenue collected over the period 2010-2015 in Alba County.

From Figure 1 we can observe that in Alba County in the analyzed period, less 2014 , there was an increase of revenue, both on each type of budget (excepting unemployment insurance budget in 2011) and on the total consolidated general budget. In 2014 there was a slight decline of revenues at the state budget and at consolidated budget, situation that was remedied in 2015 .

Thus, we see an increase of state budget revenues in 2015 compared to 2010 with $220.24 \%$, at the social insurance budget by $21.9 \%$, then at the health insurance budget by $51 \%$ and at the unemployment insurance budget with $56.42 \%$. On the total consolidated general budget the increase of revenue was with $110.4 \%$. This shows the efficiency of tax administration activity in Alba County. 
Radu C.F., Dumiter F.C., Dudas L., Jimon S. (2017)

Study on budget revenue collection, shadow economy and tax losses caused by it

Table 1. Evolution of the main budgetary revenue realized over the period 2010-2015 in Alba County, thousand lei

\begin{tabular}{|l|c|c|c|c|r|r|r|}
\hline & 2010 & 2011 & 2012 & 2013 & 2014 & 2015 & $\begin{array}{c}2015 / \\
2010 \%\end{array}$ \\
\hline $\begin{array}{l}\text { State } \\
\text { budget }\end{array}$ & 359883.06 & 401411.33 & 418223.48 & 467037.00 & 426896.10 & 1152474 & 320.24 \\
\hline $\begin{array}{l}\text { Social } \\
\text { insuran. } \\
\text { budget }\end{array}$ & 350305.50 & 356542.83 & 381938.48 & 409874.79 & 416561.72 & 427038 & 121.90 \\
\hline $\begin{array}{l}\text { Health } \\
\text { insuran. } \\
\text { budget }\end{array}$ & 132528.85 & 157733.65 & 159844.63 & 162613.62 & 172318.60 & 200163 & 151.03 \\
\hline $\begin{array}{l}\text { Unempl. } \\
\text { insuran. } \\
\text { budget }\end{array}$ & 12204.96 & 11498.46 & 12572.89 & 13182.04 & 13737.04 & 19091 & 156.42 \\
\hline $\begin{array}{l}\text { Consolid } \\
\text { general } \\
\text { budget }\end{array}$ & 854922.37 & 927186.27 & 972579.48 & 1052707.45 & 1029513.46 & 1798766 & 210.40 \\
\hline
\end{tabular}

Source: processing based on the data from the Performance Report 2015 DGRFP Brasov, Performance Report 2013 DGRFP Brasov and 2011 Performance Report of DGFP Alba

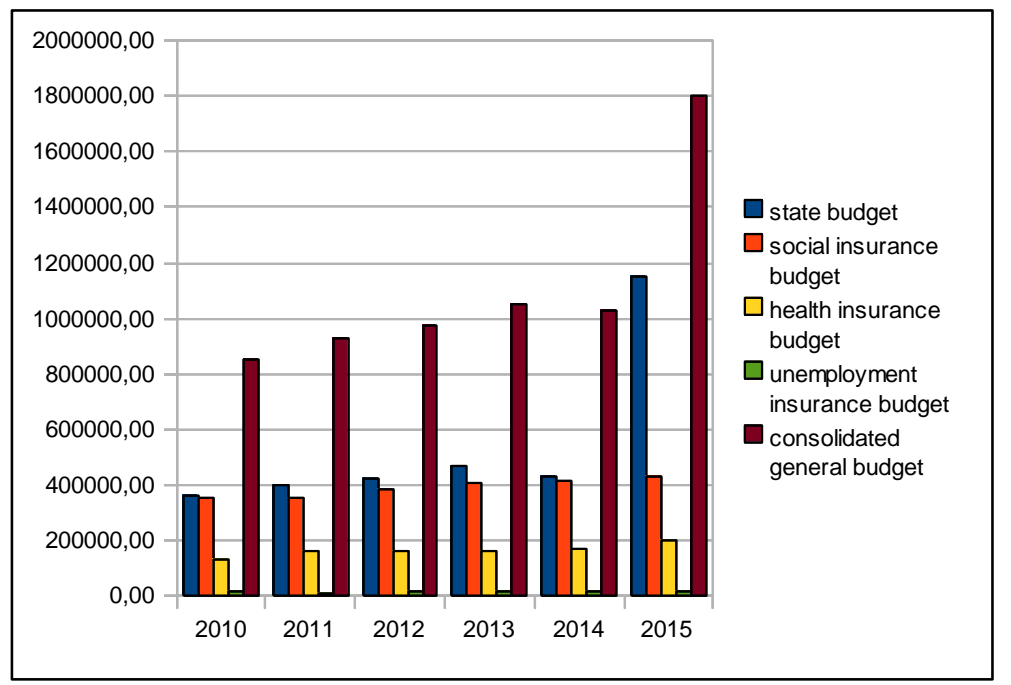

Figure 1. Evolution of revenues to consolidated general budget, Alba, 2010-2015 Source: self-processing

DE GRUYTER OPEN
Studia Universitatis "Vasile Goldis" Arad. Economics Series Vol 27 Issue 2/2017 ISSN: 1584-2339; (online) ISSN: $2285-3065$ 
Radu C.F., Dumiter F.C., Dudas L., Jimon S. (2017)

Study on budget revenue collection, shadow economy and tax losses caused by it

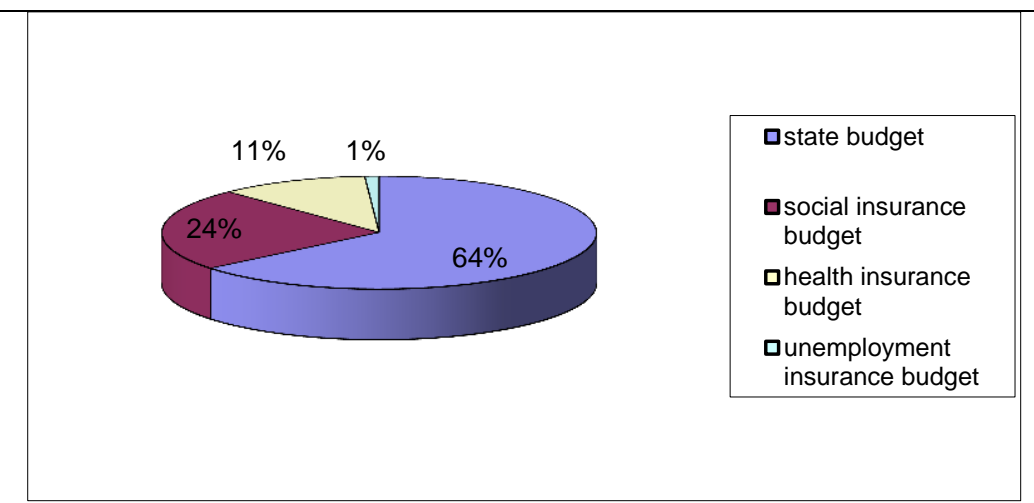

Figure 2. The share of component budgets in the general budget revenues, 2015, Alba

Source: self-processing

Figure 2 shows that in 2015, in Alba County the largest share in the total consolidated general budget had the state budget (with 64\%), on the 2nd place being the social insurance budget (with 24\%), and on the 3rd place the health insurance budget (with 11\%).

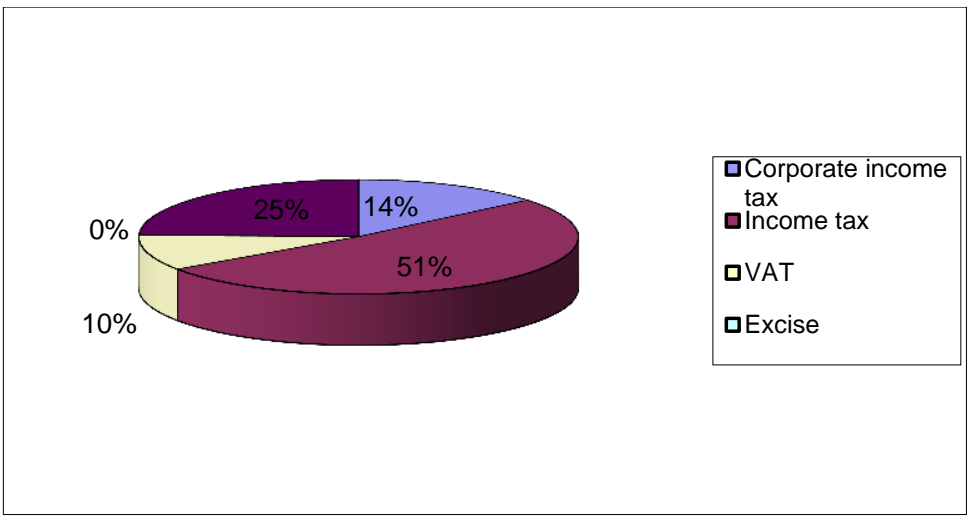

Figure 3. The share of the main budgetary revenue in Alba County, 2014 Source: self-processing

Figure 3 shows that the largest share in the budget revenue collected in Alba county had the income tax $(52 \%)$, followed by other taxes $(24 \%)$ and on the $3^{\text {rd }}$ place we find the corporate income tax (with 14\%). We note that VAT receipts are only on the $4^{\text {rd }}$ place, going up to $10 \%$ of the total. This was due to the significant decrease of VAT receipts in 2014 compared to previous years.

8 DE GRUYTER OPEN
Studia Universitatis "Vasile Goldis" Arad. Economics Series Vol 27 Issue 2/2017 ISSN: 1584-2339; (online) ISSN: 2285 - 3065

Web: publicatii.uvvg.ro/index.php/studiaeconomia.Pages 1 - 18 
Radu C.F., Dumiter F.C., Dudas L., Jimon S. (2017)

Study on budget revenue collection, shadow economy and tax losses caused by it

Then Table 2 and Figure 4 show the situation of revenues collected to the general consolidated budget in Romania.

Table 2. The share of income in total budgetary income of consolidated general budget (billion lei)

\begin{tabular}{|l|c|c|c|c|}
\hline \multirow{2}{*}{} & \multicolumn{2}{|c|}{$\mathbf{2 0 1 4}$} & \multicolumn{2}{c|}{$\mathbf{2 0 1 5}$} \\
\cline { 2 - 5 } & $\%$ & value & $\%$ & value \\
\hline Consolidated general budget income - Total & 100 & 214,3 & 100 & 233,8 \\
\hline Corporate income tax & 5,7 & 12,2 & 5,9 & 13,8 \\
\hline Personal income tax & 11,1 & 23,7 & 11,4 & 26,7 \\
\hline Wealth tax & 2,9 & 6,2 & 2,4 & 5,7 \\
\hline VAT & 23,8 & 50,9 & 24,4 & 57,1 \\
\hline Excise & 11,2 & 24,1 & 11,1 & 26 \\
\hline Other taxes & 0,2 & 0,4 & 0,2 & 0,5 \\
\hline Social security contributions & 26,9 & 57,6 & 24,6 & 57,6 \\
\hline Non-tax income & 8,1 & 17,4 & 8,4 & 19,6 \\
\hline Amounts received from the EU & 6,2 & 13,2 & 7,4 & 17,4 \\
\hline
\end{tabular}

Source: self-processing, based on data from mfinante.ro

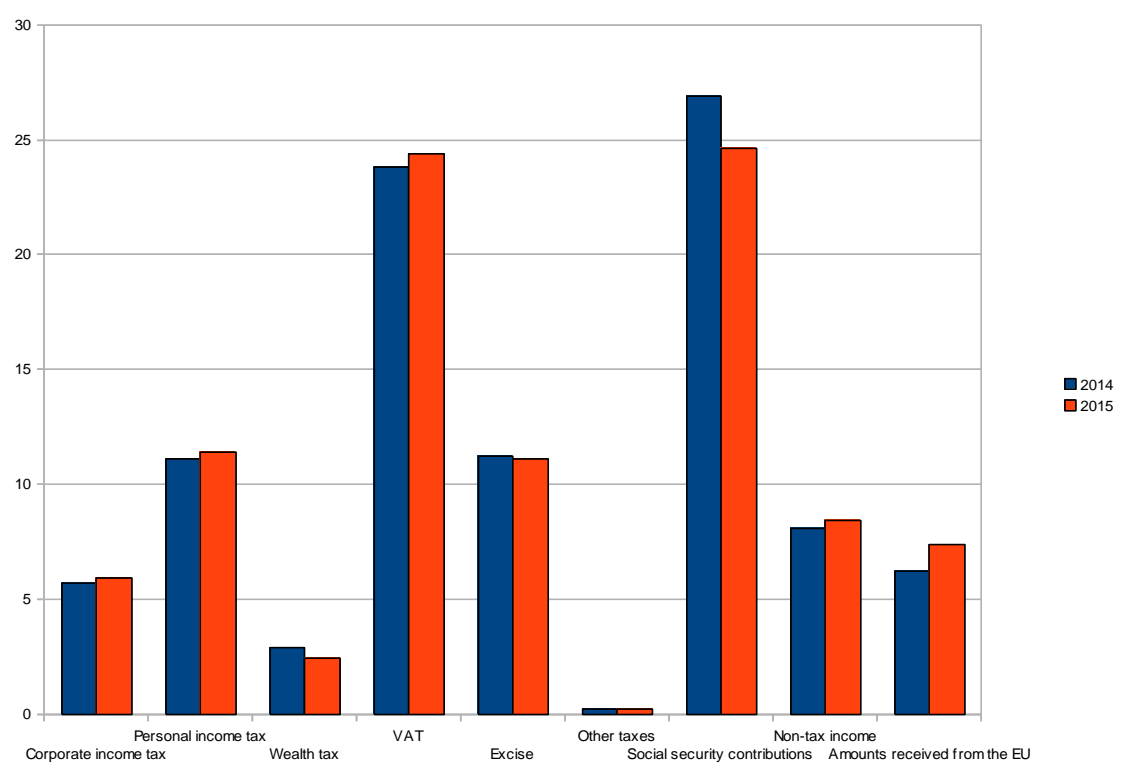

Figure 4. Evolution of the main income of the consolidated general budget between 2014-2015, in Romania

Source: self-processing

DE GRUYTER OPEN
Studia Universitatis "Vasile Goldis" Arad. Economics Series Vol 27 Issue 2/2017 ISSN: 1584-2339; (online) ISSN: 2285 - 3065 
Radu C.F., Dumiter F.C., Dudas L., Jimon S. (2017)

Study on budget revenue collection, shadow economy and tax losses caused by it

We note that the total revenues of the consolidated general budget had a slight increase in 2015 compared to 2014, from 214.3 billion to 233.8 billion lei. However in 2016 they fell to 223.7 billion lei.

The largest share in consolidated general budget had the social security contributions (with $26.9 \%$ and $24.6 \%$ ), on the 2nd place we find VAT (23.8\% and $24.4 \%$ ) and on the 3rd place, approximately equal, we find personal income tax $(11.1 \%$ and $11.4 \%)$ and excises $(11.2 \%$ and $11.1 \%)$.

Earlier we mentioned that in Alba County, in the budgetary revenues (of the state budget) we found on the first place personal income tax (with 52\%), on the 2nd place other taxes $(24 \%)$, and on the 3rd place corporate income tax (14\%). VAT was only on the 4th position, due to a significant decrease in VAT receipts in 2014 compared to previous years. Also the excises had very low values (only $0.13 \%$ of the total).

So comparing the situation in Alba County to that of consolidated general budget, we see that in Alba County prevailed other revenues than in the consolidated general budget of Romania. But at both the county and country level revenues increased in 2015 compared to 2014, which was a good situation.

Next we point out a few aspects of the tax audit activity in the Brasov region, of which Alba County belongs.

In 2015 the control organs of the Fiscal Inspection Activity from D.G.R.F.P. Brasov conducted 6631 checks to taxpayers, individuals and companies, and as a result they established additional amounts totaling 1,453,848,382 lei. As a consequence of deficiencies found 817 taxpayers were penalized with contravention fines amounting to 1,743,959 lei. They also made penal complaints for 299 taxpayers who created prejudice to consolidated general budget totaling 697,550,941 lei (according to Performance Report DGRFP Brasov 2015, p. 51).

Therefore voluntary tax compliance of individuals is an important factor to enhance the collection of budget revenues. When the level of tax compliance is high, tax evasion will be lower, and vice versa. Precisely for this reason, of decreasing tax evasion it is important to understand the reasons that lead people to pay their taxes. And the tax administration should contribute to encouraging and constantly improving the level of voluntary tax compliance, because this leads to rapid collection of incomes with low costs.

As we have shown above, people usually choose to pay their taxes because they are afraid they will be caught and punished. For this reason, in order to reduce tax evasion it is necessary to intensify the control actions of the tax authorities. But the value of fines applied is also important. We believe that the fines should be high 
enough to persuade taxpayers to declare their income correctly. Even if there are more fines, they will not have the desired effect if their value is relatively low.

We consider that the payment of taxes is explained to some extent by morality or moral factors, and then by fear of being caught and punished. We believe that the most important reason for tax compliance is or should be the positive incentives, meaning payment of taxes in exchange for goods and services offered by the state. Here we can talk of the phenomenon of reversibility of taxes, regarding individuals viewed as a whole.

\subsection{Tax burden, shadow economy and tax losses}

In the following we intend to analyze the data concerning shadow economy in correlation with tax burden and also with the loss at budget revenues due to shadow economy for 32 countries ( $28 \mathrm{EU}$ countries and four other non-EU countries), in 2013.

We opted for year 2013 because we wanted the data for the three aspects analyzed to be comparable: tax burden, the shadow economy and tax losses due to it, and in the case of tax losses data are available only for 2013.

Figures 5 and 6 highlight the shadow economy, the tax burden and tax loss due to shadow economy, for the 32 analyzed countries.

As we can see, the shadow economy as percentage of GDP has the highest values in Romania and Croatia (28.4\%) and also in Bulgaria (31.2). But the lowest values are in Switzerland $(7.1 \%)$ and the US (6.6\%). The average of the analyzed countries is $18.1 \%$, therefore in our country shadow economy is about $10 \%$ higher than the average of the 32 countries.

In this context it is suggestive Osmani's remark (2015, p. 21): the high level of the shadow economy, tax evasion and corruption is the result of a low cultural level and civilization of the Southeast Europe countries (SEE countries).

Concerning tax burden, the highest values occur in Denmark (48.6\%) and Belgium (47.8\%). In contrast, the lowest values appear in Switzerland (27.2\%) and USA (25.4\%). Romania has a tax burden of $27.4 \%$ of GDP and it is among the countries with a low tax burden, the average of the analyzed countries being $36 \%$.

Tax loss due to shadow economy is the highest in Bulgaria (18.8), Romania (17.1) and Croatia (17.1) and at the opposite side are Switzerland (4.3\%) and USA (4\%). We note that the average of the analyzed countries is $6.4 \%$ and the EU average is $8.6 \%$. So our country is at the top of the ranking for the 32 analyzed countries, both in terms of shadow economy, and of tax losses due to it. Therefore we believe that in our country, it is necessary for measures to be taken which to have the effect of reducing the shadow economy to a greater extent. In this way budget revenues would increase and there would be more resources to support public spending. 
Radu C.F., Dumiter F.C., Dudas L., Jimon S. (2017)

Study on budget revenue collection, shadow economy and tax losses caused by it

We chose to study the shadow economy in correlation with the tax burden in order to notice if there is a direct link between the two. But we found that countries where the shadow economy presents the highest values are not countries where the tax burden has the highest levels. For example in Romania and Bulgaria the tax burden is below the EU average (40\%) and below the average of the analyzed countries (36\%), but they are on the first places regarding the shadow economy (around 30\%). Also, some EU developed countries such as France and Austria have a shadow economy below $10 \%$ of GDP, but instead, here the tax burden has a quite high value - France (47.3\%) and Austria (43.4\%). We mention that the highest tax burden is of $48.6 \%$ in Denmark.

Generally countries with a high tax burden, have also a considerable level of labour taxation. However, it is important to notice that labor taxes are high in many countries, mainly due to high social security contributions levied on wages. These social contributions have the purpose to finance social security programs, which are very expensive especially in the European countries (Radu et al., 2015, p. 1).

Countries where the tax burden and the shadow economy have close values are: Lithuania, Romania, Latvia, Bulgaria and Turkey.

Regarding the shadow economy, we can mention that in 8 of the 32 analyzed countries it is below $10 \%$, then 11 countries have values between $10-20 \%$ and 13 countries have values between $20-30 \%$. Bulgaria is the only country with a shadow economy over $30 \%$ of GDP.

Then figure 7 presents the evolution of the shadow economy during 2003-2015 in Romania, also for the EU average and the OECD average as \% of GDP.

We note that throughout the analyzed period, shadow economy in Romania was each year by approx. 10\% above the EU average and with $11-12 \%$ above the OECD average. But a good aspect is that the shadow economy of our country and also the EU average and the OECD average decreased over time.

Regarding the relationship between tax burden and tax evasion, we mention that some authors brought into discussion that high tax burden could have a negative effect on tax compliance. Thus a higher tax burden may increase the attractiveness of behaving illegally and here matters more the application of tax rates by offering tax concessions and exemptions (Torgler et al., 2009, p. 17-18). Tax rates have shown to be the main factor explaining the frequency of tax evasion. Higher tax rates can lead to more evasion. However some econometric studies have found a positive relationship between the two, while others have found an opposite link (Bayer, Sutter, 2004, p. 26). 
Radu C.F., Dumiter F.C., Dudas L., Jimon S. (2017)

Study on budget revenue collection, shadow economy and tax losses caused by it

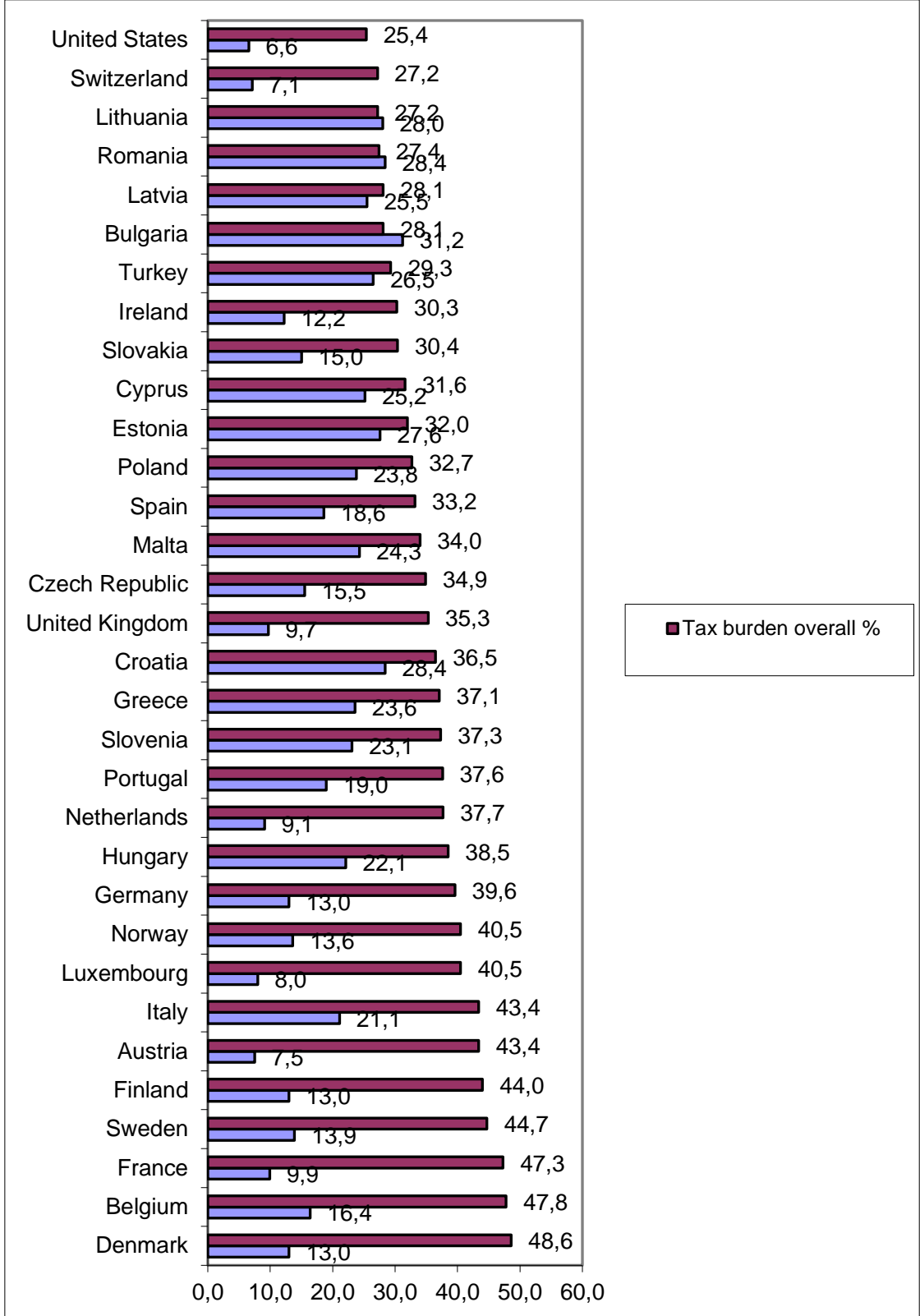

Figure 5. Shadow economy \% of GDP and tax burden overall \%, 2013

Source: self-processing according to Schneider (2016)

DE GRUYTER Studia Universitatis "Vasile Goldis" Arad. Economics Series Vol 27 Issue 2/2017 
Radu C.F., Dumiter F.C., Dudas L., Jimon S. (2017)

Study on budget revenue collection, shadow economy and tax losses caused by it

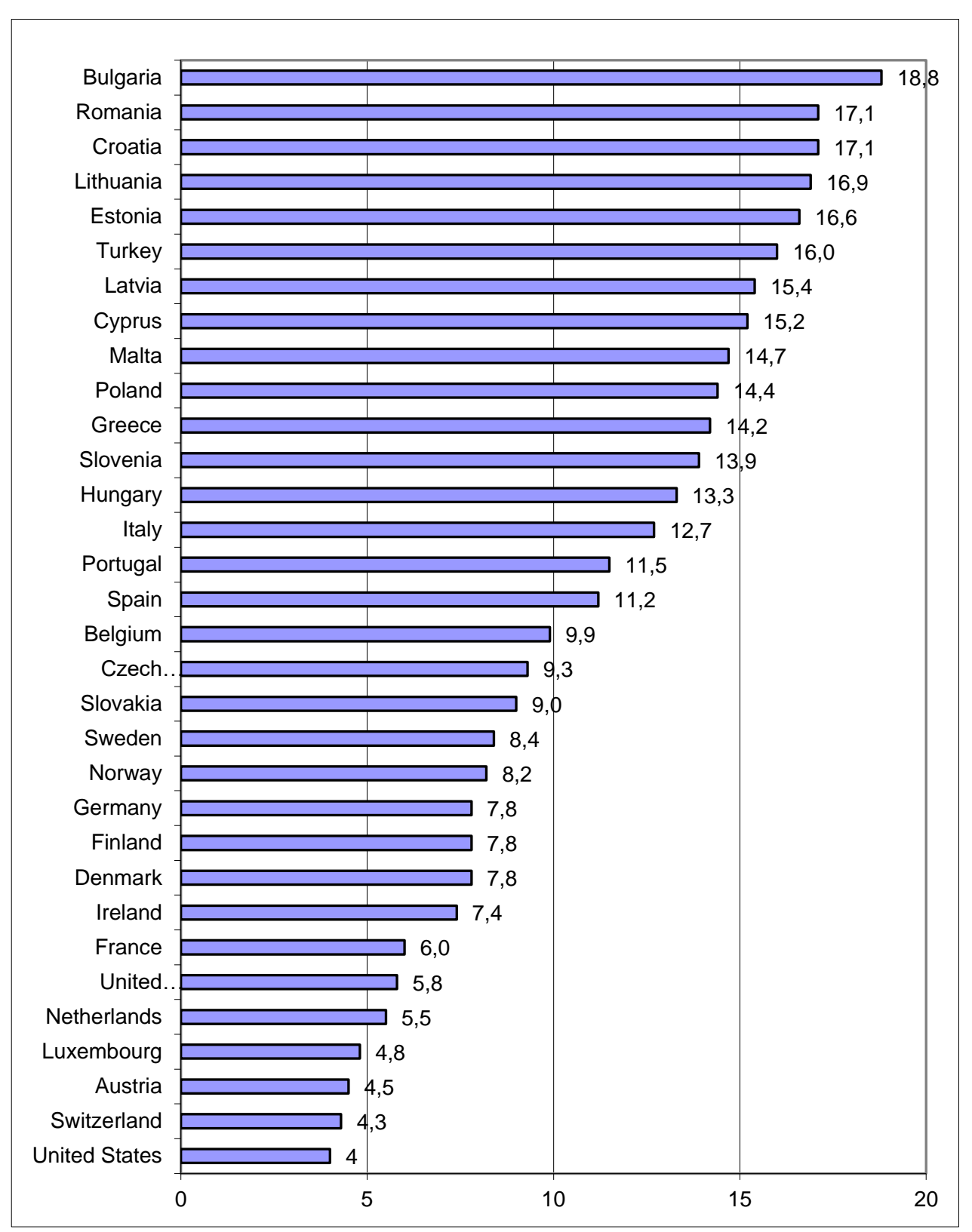

Figure 6. Tax loss due to shadow economy \% of total tax, 2013

Source: self-processing according to Schneider (2016)

DE GRUYTER

OPEN
Studia Universitatis "Vasile Goldis" Arad. Economics Series Vol 27 Issue 2/2017

ISSN: 1584-2339; (online) ISSN: $2285-3065$

Web: publicatii.uvvg.ro/index.php/studiaeconomia.Pages 1 - 18 
Radu C.F., Dumiter F.C., Dudas L., Jimon S. (2017)

Study on budget revenue collection, shadow economy and tax losses caused by it

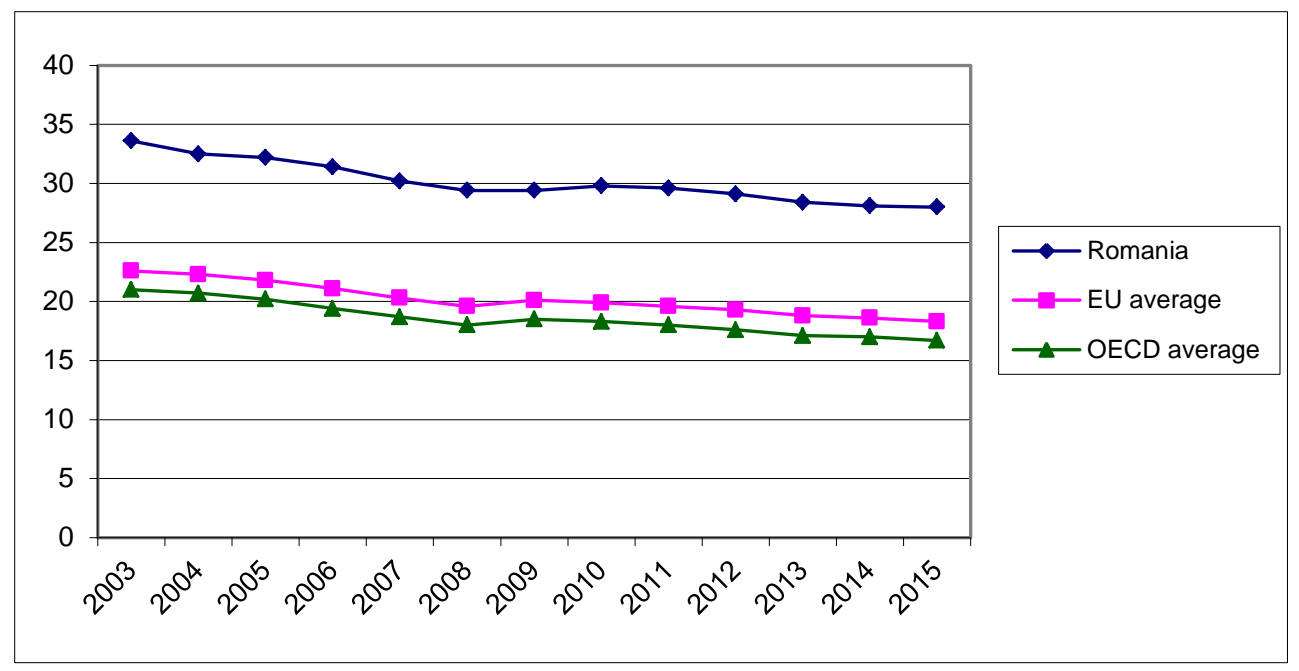

Figure 7. Evolution of the shadow economy between 2003-2015 (in Romania, EU average and OECD average as \% of GDP)

Source: self-processing according to Schneider (2015)

We mention that the data for 2015 are projections.

Over time many economists and politicians were concerned about maintaining the tax burden in bearable limits. However, in most countries the tax burden has increased very much in time. There were many who warned that at some point the tax is devouring itself. Arthur Laffer demonstrated graphically by the famous curve that bears his name, the correlation between taxes collected to the budget and the level of statutory tax rates. As long as tax burden remains reasonable, the interest for work and business is not affected, and the temptation for tax evasion is less. But when the tax burden becomes unbearable the economic Malthusianism appears and adverse reaction towards taxes does not fail to appear (Tulai, 2003, p. 296).

\section{Conclusions}

In the first part of the paper we analyzed the issues concerning collection of budgetary revenues first at the county level, then at the country level.

Then in the second part we focused on the tax burden, shadow economy and tax losses due to it.

As we mentioned before, we consider that individuals pay taxes, firstly due to real or perceived benefits that might be obtained by paying taxes. Secondly, for fear of 
Radu C.F., Dumiter F.C., Dudas L., Jimon S. (2017)

Study on budget revenue collection, shadow economy and tax losses caused by it

negative consequences that could arise due to non-payment of them and only thirdly (and to a lesser extent) because of "fiscal consciousness" and due to a desire to help achieve "the common good".

Therefore voluntary tax compliance of individuals is an important factor to improve the collection of budget revenues. When the level of tax compliance is high, tax evasion will be lower, and vice versa.

In the context of economic and financial crisis that many countries have faced in recent years it is necessary to make substantial efforts for a better tax administration and for tax avoidance decrease. As a result of lower tax evasion a restructuration of the tax system is possible as well as the increase of revenue collected to the budget; economic growth can also be achieved which is so necessary in many countries. So fighting against tax evasion must be a priority for governments in each country, because in this way they can get additional resources for providing citizens health, education, social security and other public services.

The shadow economy is treated as activities that avoid payment of taxes of all kinds. Fighting the shadow sector of the economy, tax evasion and corruption should be implemented and practiced as a joint responsibility of government, the legal economic sector, nongovernment and civil organizations and the population. That is why only a functional coordination between all parties within a national strategy can provide positive results in fighting these negative phenomena in the long run (Osmani, 2015, p. 21).

From the analysis of the 32 countries we found that countries where the shadow economy presents the highest values are not countries where the tax burden has the highest levels.

After analyzing the sample of 32 countries, we noticed that Romania, along with Bulgaria and Croatia are in the first positions concerning the shadow economy and tax losses due to it. Therefore it is necessary to insist towards the adoption of some measures that effectively lead to the increase of tax compliance and to considerably decrease of tax evasion. In this way budget revenues would grow and there would be more resources to support public spending.

Further we make some remarks on ways of reducing tax evasion and increasing revenues collected to the budget.

The tax authorities should be concerned for combating tax evasion in all aspects, for increasing efficiency and dynamics of income collection and also for increasing voluntary tax compliance.

In order to improve efficiency at the level of budgetary revenues the following important issues should be taken into account: simplifying the tax system, lowering the tax burden, reducing tax evasion and increasing the collection level of taxes. 
Regarding the measures to increase budget revenues we can suggest to increase the tax base, but also a growth of employees revenues and number of jobs, which leads to an increase in the payroll tax and social security contributions collected to the budget.

Actions taken to reduce tax evasion must consider its prevention and detection and also firmly combating it by all means. It is then necessary to intensify tax audits to taxpayers and focus towards high-risk areas.

In parallel tax authorities should also aim at the improvement of fiscal discipline by increasing voluntary tax compliance. It is necessary to continue the process of tax returns simplification and development of electronic declaration. It is also necessary a modernization of working tools, the development of computer systems, then improving methods of interaction with taxpayers. It would be also useful to draw up some studies highlighting the satisfaction level of taxpayers regarding the assistance services offered.

\section{References:}

1. Alstadsaeter, A., Jacob, M. (2013). The effect of awareness and incentives on tax evasion, Retrieved from http://ideas.repec.org/p/ces/ceswps/_4369.html Accessed January 2014.

2. Bayer, R., Sutter, M. (2004). The excess burden of tax evasion - An experimental detection-concealment contest, Retrieved from http://ideas.repec.org/p/wpa/wuwpex/ 0412003.html Accessed January 2014.

3. Bernasconi, M., Corazzini, L., Seri, R. (2011). Tax Evasion: Does the Tax Burden Matter? Retrieved from http://ideas.repec.org/p/slp/islawp/islawp43.html Accessed February 2014.

4. Dumiter, F., Todor, S. (2014). Modeling the relationship between foreign direct investments and economic growth - evidence from Central and Eastern European countries, Studia Universitatis „Vasile Goldis” Arad, Economics Series, Volume 24, Issue 2/2014, pp. $1-18$.

5. Kirchler, E., Muehlbacher, S., Kastlunger, B., Wahl, I. (2007). Why Pay Taxes? A Review of Tax Compliance Decisions, Retrieved from http://ideas.repec.org/p/ays/ ispwps/paper0730.html Accessed January 2014.

6. Maciejovski, B., Schwarzenberger, H., Kirchler, E. (2011). Rationality vs. Emotions: The Case of Tax Ethics and Compliance, Retrieved from http://papers.ssrn.com/sol3/papers.cfm?abstract_id=1831077 Accessed February 2014.

7. Murphy, R. (2011). The Cost of Tax Abuse: A briefing paper on the cost of tax evasion worldwide, The Tax Justice Network, Chesham (UK), November 2011.

8. Osmani, R. (2015). The level of the shadow economy, tax evasion and corruption: The empirical evidence for SEE countries, SEEU Review Volume 11 Issue 2, pp. 7-23, Retrieved from https://www.degruyter.com/downloadpdf/j/seeur.2015.11. issue-2/seeur2015-0025/seeur-2015-0025.xml Accessed September 2016.

Studia Universitatis "Vasile Goldis" Arad. Economics Series Vol 27 Issue 2/2017

ISSN: 1584-2339; (online) ISSN: $2285-3065$

Web: publicatii.uvvg.ro/index.php/studiaeconomia.Pages $1-18$ 
Radu C.F., Dumiter F.C., Dudas L., Jimon S. (2017)

Study on budget revenue collection, shadow economy and tax losses caused by it

9. Panades, J., (2004). Tax evasion and relative tax contribution, PUBLIC FINANCE REVIEW, Vol. 32 No. 2, March 2004 183-195, Retrieved from pareto.uab.es/jpanades/papers/public_finance_review.pdf Accessed January 2014.

10. Papp, T., Takats, E., (2008). Tax rate cuts and tax compliance - the Laffer curve revisited, IMF Working Paper, Retrieved from http://ideas.repec.org/p/imf/imfwpa/087.html Accessed February 2014.

11. Radu, C.F. (2014a). About tax compliance: some reasons why people pay their taxes, The Scientific Journal of Humanistic Studies, no. 10 /year 6/2014, pp. 107-112.

12. Radu, C.F. (2014b). Aspects concerning tax evasion in Alba County and Brasov Region, Studia Universitatis „Vasile Goldis” Arad, Economics Series, Volume 24, Issue 1/2014, pp. 108-121.

13. Radu, C.F., Dumiter, F., Opreț, A. (2015). Labour taxation - A comparative study, Studia Universitatis „Vasile Goldis” Arad, Economics Series, Volume 25, Issue 1/2015, pp. $1-15$.

14. Schneider, F. (2015), Size and Development of the Shadow Economy of 31 European and 5 other OECD Countries from 2003 to 2015: Different Developments, Retrieved from: http://www.econ.jku.at/members/Schneider/ files/publications/2015/ShadEcEurope31.pdf, Accessed march 2017

15. Schneider, F. (2016). Tax Losses due to Shadow Economy Activities in OECD Countries from 2011 to 2013: A preliminary calculation, Turkish Economic Review Vol. 3 (1) pp. 8-9, Retrieved from http://www.kspjournals.org/index.php/TER/ article/view/686/720, Accessed September 2016.

16. Torgler, B., Schneider, F., Schaltegger, C. (2009). Local Autonomy, Tax Morale and the Shadow Economy, Retrieved from www.crema-research.ch/papers/ 2008-24.pdf Accessed January 2014.

17. Tulai, C. (2003). Finanțele publice si fiscalitatea, Editura Casa Carții de Stiința, ClujNapoca.

18. *** Raport de performanța 2013 - Direcția Generala Regionala a Finanțelor Publice Brasov, Retrieved from http://bv.finantepublice.ro/html/despre_noi/index.php3 Accessed July 2016.

19. *** Raport de performanța 2015 - Direcția Generala Regionala a Finanțelor Publice Brasov, Retrieved from https://static.anaf.ro/static/10/Brasov/Brasov/ Raport_performanta_2015.pdf Accessed July 2016.

20. *** Raportul de performanța pe anul 2011 al Direcției Generale a Finanțelor Publice a județului Alba, Retrieved from static.anaf.ro/static/3/Alba/RAPORT_PERFORMANTA _2011.pdf Accessed July 2016. 